\title{
Silicon Solar Cells: Recombination and Electrical Parameters
}

\author{
Saïdou Madougou ${ }^{1}$, Mohamadou Kaka ${ }^{1}$ and Gregoire Sissoko ${ }^{2}$ \\ 1 University Abdou Moumouni of Niamey, BP 10963 - Niamey \\ 2Université Cheikh Anta Diop de Dakar, \\ ${ }^{1}$ Niger \\ ${ }^{2}$ Senegal
}

\section{Introduction}

Nowadays, the world's energy needs are growing steadily. However, the conventional sources of energy are limited.

Solar energy such as photovoltaic energy (PV) is the most available energy source which is capable to provide this world's energy needs. The conversion of sunlight into electricity using solar cells system is worthwhile way of producing this alternative energy. The history of photovoltaic energy started in 1839 when Alexandre-Edmond Becquerel discovered the photovoltaic effect (S.M. SZE 1981, W. Shockley 1949). Photovoltaic system uses various materials and technologies such as crystalline Silicon (c-Si), Cadmium telluride (CdTe), Gallium arsenide (GaAs), chalcopyrite films of Copper-Indium-Selenide (CuInSe 2 ), etc (W. Shockley 1949, W. Shockley et al. 1952). Now, silicon solar cells represent $40 \%$ of the world solar cells production and yield efficiencies well higher than $25 \%$ (A. Wang et al 1990). In solar technology, the main challenge of researchers is to improve solar cells efficiency. Due to this challenge, several investigations have been developed to characterize the solar cells by the determining their parameters. Indeed, it is important to know these parameters for estimating the degree of perfection and quality of silicon solar cells.

This chapter first describes the device physics of silicon solar cells using basic equations of minority carriers transport with its boundary conditions, the illumination mode and the recombination mechanisms. Then, a silicon solar cells recombination and electrical parameters are presented (S. Madougou et al 2005a, 2007b). Finally, some methods of determination of these parameters are described.

\section{Overview of silicon material}

In most cases, solar cells are manufactured on a silicon material. Its proportion represents $40 \%$ of world-wide semiconductor solar cells production. Pure silicon material is founded directly in solid silica by electrolysis. The production of silicon by processing silica $\left(\mathrm{SiO}_{2}\right)$ needs very high energy and more efficient methods of synthesis. Also, the most prevalent silicon solar cell material is crystalline silicon (c-Si) or amorphous silicon (a-Si).

Source: Solar Energy, Book edited by: Radu D. Rugescu, ISBN 978-953-307-052-0, pp. 432, February 2010, INTECH, Croatia, downloaded from SCIYO.COM 
Crystalline silicon can be separated into multiple categories according to its crystallinity and its crystal size. These include: monocrystalline silicon, poly or multicrystalline silicon, Ribbon silicon and new structures.

Compared to amorphous silicon, crystalline silicon absorbs the visible part of the solar spectrum more than infrared portion of spectrum. Crystalline silicon has a smaller band gap $(\mathrm{Eg}=1.1 \mathrm{eV})$ than amorphous silicon $(\mathrm{Eg}=1.75 \mathrm{eV})$ in live with Shockley-Hall-Read's recombination process experiment (W. Shockley 1949).

Crystalline silicon solar cells generate approximately $35 \mathrm{~mA} / \mathrm{cm}^{2}$ of current, and voltage 550 $\mathrm{mV}$. Its efficiency is above $25 \%$. Amorphous silicon solar cells generate $15 \mathrm{~mA} / \mathrm{cm} 2$ density of current and the voltage without connected load is above $800 \mathrm{mV}$. The efficiency is between 6 and $8 \%$ (S. W. Glunz et al. 2006).

But, all solar cells require a light absorbing material contained within the cell structure to absorb photons and generate electrons (G. Sissoko et al. 1996).

\section{Device physics of silicon solar cells}

\subsection{Silicon solar cells}

Commonly, most silicon solar cells are configured in N-P junctions or vice versa (S.M. SZE 1981) in one side and $\mathrm{N}^{+}-\mathrm{N}-\mathrm{P}^{+}$structure (or vice versa) for double sides named bifacial silicon solar cell (S. Madougou et al. 2004, 2005a, 2005b, 2007a et 2007b). Silicon solar cells have all contacts on the back of the cell. Figure 1 shows an example of silicon solar cell with its contacts.

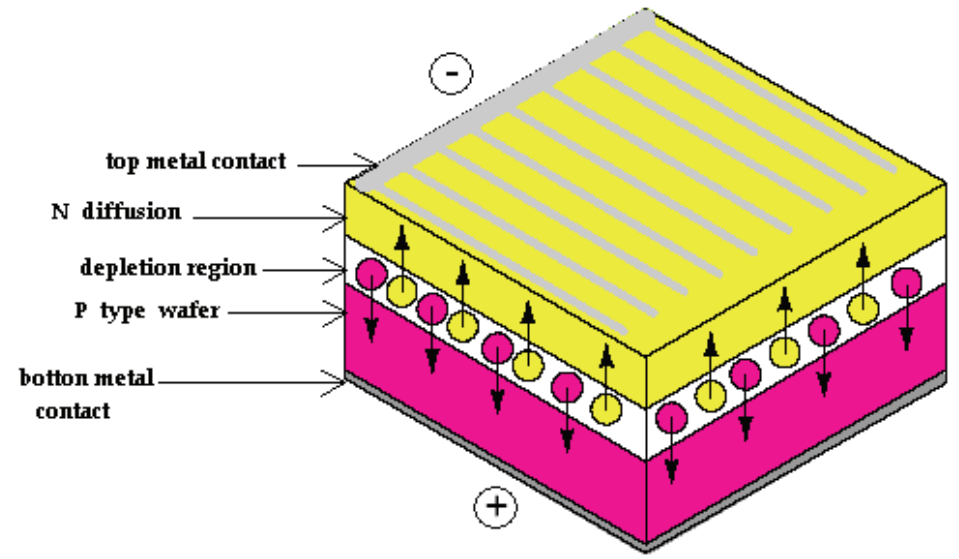

Fig. 1. Silicon Solar cell with its contacts

In this section, we will study the structure and the operation of N-P junction (monofacial and bifacial silicon solar cells).

\subsubsection{Monofacial silicon solar cell}

N-P junction or a P-N junction is a one side solar cell (W. Shockley 1949). When a P-type is placed in intimate contact with an N-type, a diffusion of electrons occurs from the region of high electron concentration (N-type) into the region of low electron concentration (P-type). Figure 2 shows the N-P junction and its forward biased with its corresponding diode schematic symbol and its I-V characteristic curve. 


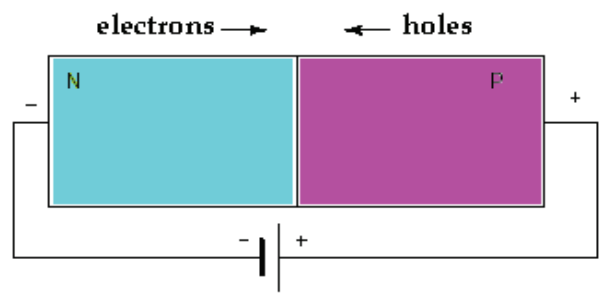

(a)
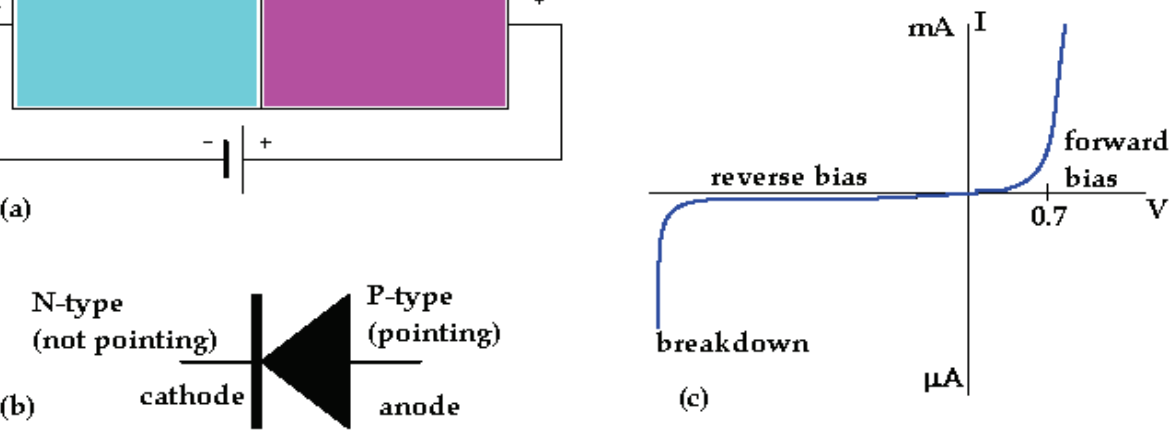

Fig. 2. N-P junction: (a) Forward biased N-P junction, (b) Corresponding diode schematic symbol (c) silicon diode I versus $\mathrm{V}$ characteristic curve.

\subsubsection{Bifacial silicon solar cell}

Bifacial silicon solar cell is a double sided silicon solar cell with $\mathrm{N}^{+}-\mathrm{N}_{-} \mathrm{P}^{+}$or $\mathrm{N}^{+}-\mathrm{P}_{-} \mathrm{P}^{+}$ structure or vice versa (S. Madougou et al. 2004).

A bifacial silicon solar cell with $\mathrm{N}^{+}-\mathrm{P}_{-} \mathrm{P}^{+}$structure has an $\mathrm{N}^{+}-\mathrm{P}$ front side (surface) and $\mathrm{P}^{+-} \mathrm{P}$ back side (surface). This back surface $\left(\mathrm{P}^{+}-\mathrm{P}\right)$ is an important seat of a Back Surface Field (J. D. Alamo et al. 1981). In some solar cells, the front surface doping density ranges from $10^{17}$ to $10^{19} \mathrm{~cm}^{-3}$. In the base, the doping ranges $10^{15}$ to $10^{17} \mathrm{~cm}^{-3}$. The bifacial silicon solar cell can be illuminated from the front side, the back side or simultaneously from both sides as shown in figure 3 .

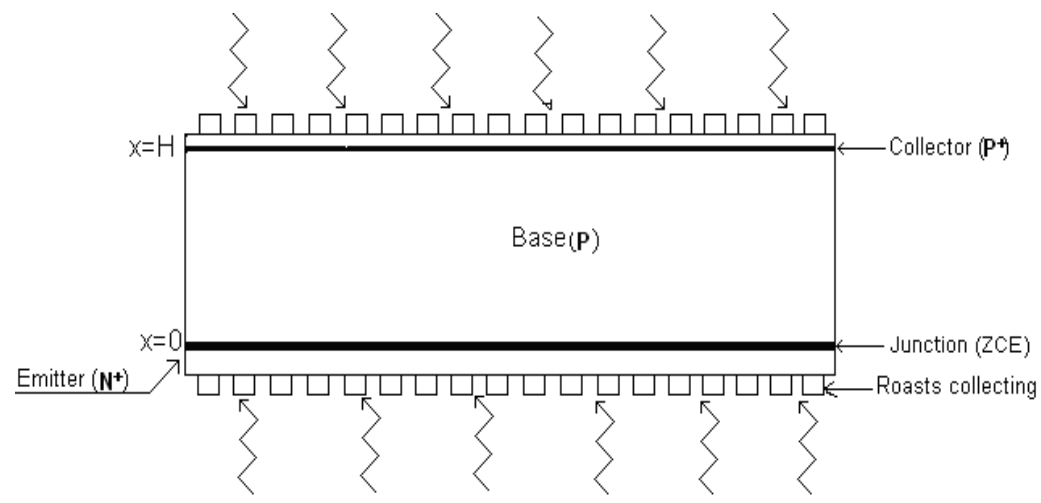

Fig. 3. Bifacial silicon solar cell with n+-p-p+ structure.

\subsection{Recombination mechanisms}

In a conventional silicon solar cell, recombination can occur in five regions (W. Shockley 1949):

- $\quad$ at the front surface;

- $\quad$ at the emitter region $\left(\mathrm{N}^{+}\right)$;

- $\quad$ at the junction (the depletion region of the junction);

- $\quad$ at the base region $(\mathrm{P})$; 
- $\quad$ at the back surface.

They are mainly two types of recombination: the recombination mechanisms in bulk (volume) and the surface recombination.

\subsubsection{Recombination mechanisms in bulk of the silicon solar cell}

In a bulk of the silicon solar cell, three fundamental recombination mechanisms are produced.

- Auger recombination. We have Auger recombination when the energy of the electron which falls in the valence band is transferred as kinetic energy to:

- $\quad$ another free electron which will be transferred to a higher level in the conduction band;

- $\quad$ a hole on a deep level of the valence band.

- Shockley-Read-Hall recombination (through defect). They are twofold:

- $\quad$ those due to defects in the crystal lattice or chemical impurities;

- those that occur when a deep level captures an electron.

- Radiative or band-to-band recombination. When a junction is forward biased, the recombination can be radiative. It is the opposite of the absorption phenomenon. The free carriers go directly from the conduction band to the valence band by emission of photon. This recombination is related by the lifetime $\tau$ of the excess minority carriers. They also intervene in the diffusion of charge carriers through the term $U(x)$ given by the expression:

$$
U(x)=\frac{\delta n(x)}{\tau}
$$

Where, $\delta n(x)$ is the excess minority carriers density, and $\tau$ is its lifetime.

\subsubsection{Surface recombination}

The many faults that characterize the surface of a semiconductor disrupt its crystalline structure. The Surface recombination corresponds to a phenomenon where excited electrons in the conduction band recombine with holes in the valence band via defect levels at the surface, called surface states. These surface states are the result of the abrupt discontinuity of a crystalline phase at the surface, which forms unsatisfied dangling silicon bonds.

\subsection{Illumination mode}

The solar cells can be under monochromatic light (single wavelength), constant multispectral light or variable and intense light concentration (more than 50 suns) or under other mode. The optical generate rate $G(x)$ of monochromatic light is given by (S. Madougou 2007b):

$$
G(x)=\alpha(1-R) \Phi_{0} \exp (-\alpha x)
$$

Where, $R$ is the reflectivity coefficient, $\alpha$ is the optical absorption coefficient and $\Phi_{0}$ is the incident flux of monochromatic light.

When the solar cell is illuminated by the multispectral light the generated rate $G(x)$ is given by (S. Madougou 2007a):

$$
G(x)=\sum_{i=1}^{3} a_{i}\left[\exp \left(-b_{i} x\right)\right]
$$


Where, $\mathbf{a}_{\mathbf{i}}$ and $\mathbf{b}_{\mathbf{i}}$ are the coefficients deduced from the modelling of the generation rate considered for over all solar radiation spectrums.

Figure 4 shows an experimental set-up of silicon solar cell illuminated with a direct light from a lamp.

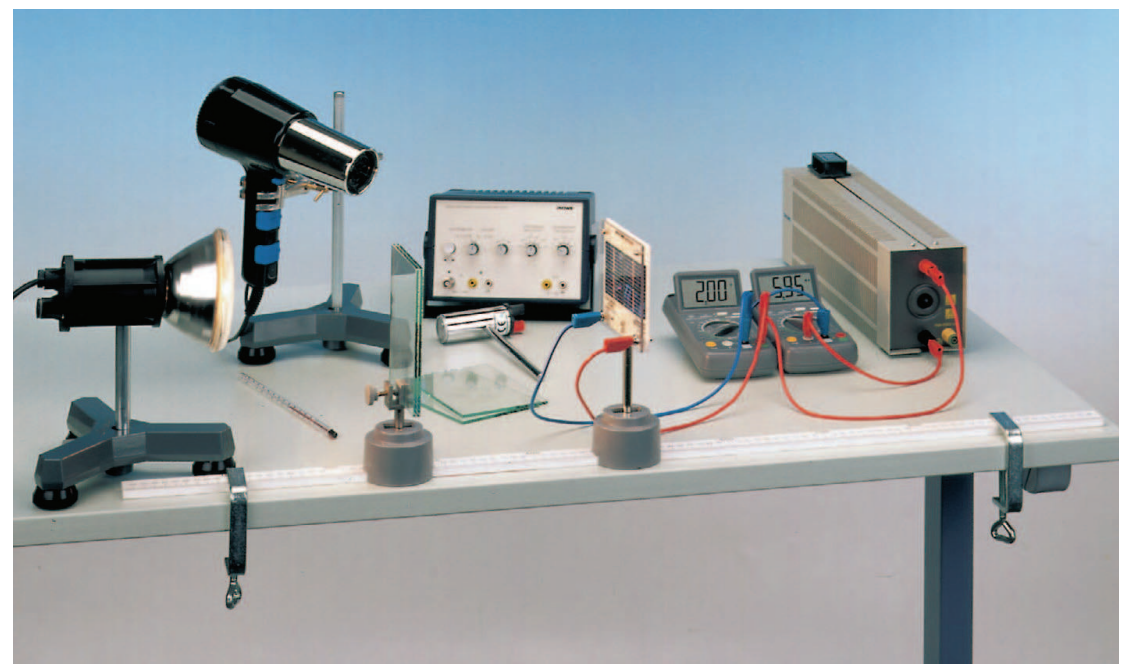

Fig. 4. Experimental set-up of silicon solar cell illuminated with a direct light from a lamp.

\subsection{Basic equations of minority carriers transport}

The basic equations describe the behaviour of the excess minority carriers in the base of the solar cell under the influence of an electric field and/or under illumination; both cause deviations from thermal equilibrium conditions. These equations can be expressed on one or two dimensions. In the following, we will work in one dimension.

\subsubsection{Poisson equation}

The Poisson equation relates the gradient of the electric field $E$ to the space charge density $\rho$. According to W. Shockley(1949), it is given as:

$$
-\frac{d^{2} \phi(x)}{d x^{2}}=\frac{d E(x)}{d x}=\frac{\rho}{\varepsilon_{0} \varepsilon}
$$

Where, $\phi$ is the electrostatic potential, $\varepsilon_{0}$ is the permittivity of free space and $\varepsilon$ is the static relative permittivity of medium.

In the same conditions, the electrons' current density $I_{n}$ and the holes' current density $I_{p}$ are obtained as follows:

$$
\begin{aligned}
& I_{n}=+q \mu_{n} n(x) E(x)+q D_{n} \frac{d n(x)}{d x} \\
& I_{p}=-q \mu_{p} p(x) E(x)+q D_{p} \frac{d p(x)}{d x}
\end{aligned}
$$


Where, $q$ is the elementary charge, $\mu_{n}$ and $\mu_{p}$ are the mobility's of electrons and holes, $D_{n}$ and $D_{p}$ are the diffusion constants related through the Einstein relationships: $D_{n}=\frac{k T}{q \mu_{n}} ; D_{p}=\frac{k T}{q \mu_{p}}$. $k$ is the Boltzmann constant.

\subsubsection{Continuity equation}

When the solar cell is illuminated, the continuity equation related to photogenerated excess minority carriers density $\delta n(x)$ in the base region of the cell is given by (G. Sissoko et al 1996):

$$
\frac{\partial^{2} \delta n(x)}{\partial x^{2}}-\frac{\delta n(x)}{L^{2}}+\frac{G(x)}{D}=0
$$

Where, $D$ is the excess minority carriers diffusion constant and $L$ is their diffusion length. $G(x)$ is the carriers generation rate in the base.

The solution $\delta n(x)$ of the continuity equation is well defined by the boundary conditions.

\subsubsection{Boundary conditions}

According to G. Sissoko et al. (1996), the boundary conditions defined by the minority carriers recombination velocities are:

- $\quad$ The emitter-base junction at $x=0$ :

$$
\left.\frac{\partial \delta n(x)}{\partial x}\right|_{x=0}=\frac{S f}{D} \delta n(0)
$$

- $\quad$ The back-surface of the base at $\mathrm{x}=\mathrm{H}$ :

$$
\left.\frac{\partial \delta n(x)}{\partial x}\right|_{x=H}=-\frac{S b}{D} \delta n(H)
$$

Where, $S b$ is the minority carriers recombination velocity at the back-surface and $S f$ is the minority carriers recombination velocity at the junction.

\subsection{Equivalent circuit of the solar cell}

To understand the electronic behaviour of a solar cell, it is useful to create its model which is electrically equivalent at the solar cell. Because no solar cell is ideal, a shunt resistance and a series resistance component are therefore added to the model to have the equivalent circuit. This equivalent circuit of the solar cell is based on discrete electrical components. Figure 5 shows an example of an equivalent circuit of a solar cell with one diode.

For the practical analysis of the solar cell performance the dark current-voltage (I-V) characteristics curve is shifted down by a light generated current $I_{L}$ resulting in the illuminated I-V characteristics.

The $I-V$ characteristic of a single-junction P-N under illumination can be written as follows:

$$
I=I_{0}\left[\exp \left(\frac{q V}{k T}\right)-1\right]-I_{L}
$$




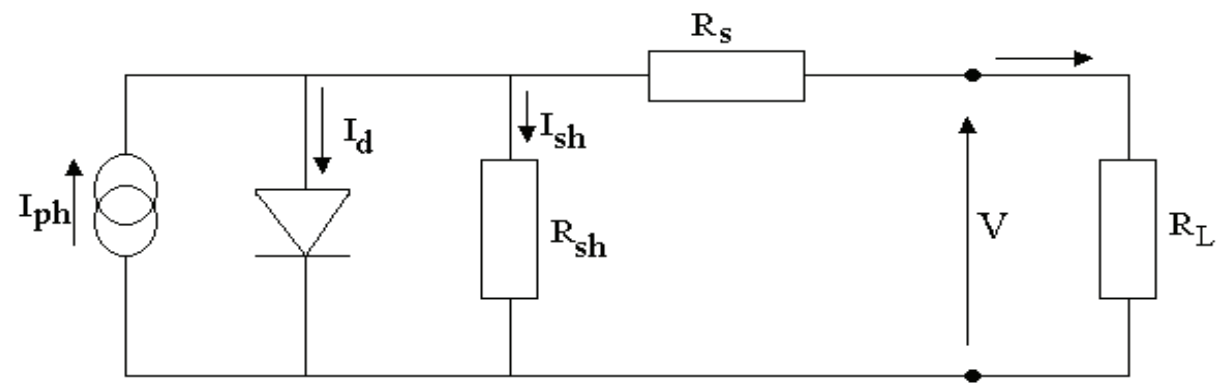

Fig. 5. Equivalent circuit of the solar cell with one diode.

And the dark current density of the P-N junction by:

$$
I_{\text {dark }}=I_{0}\left[\exp \left(\frac{q V}{k T}\right)-1\right]
$$

Where, $I_{0}$ is the reverse saturation current density, $V$ the voltage and $T$ is the absolute temperature.

Figure 6 below shows the dark and illuminated current-voltage (I-V) characteristics.

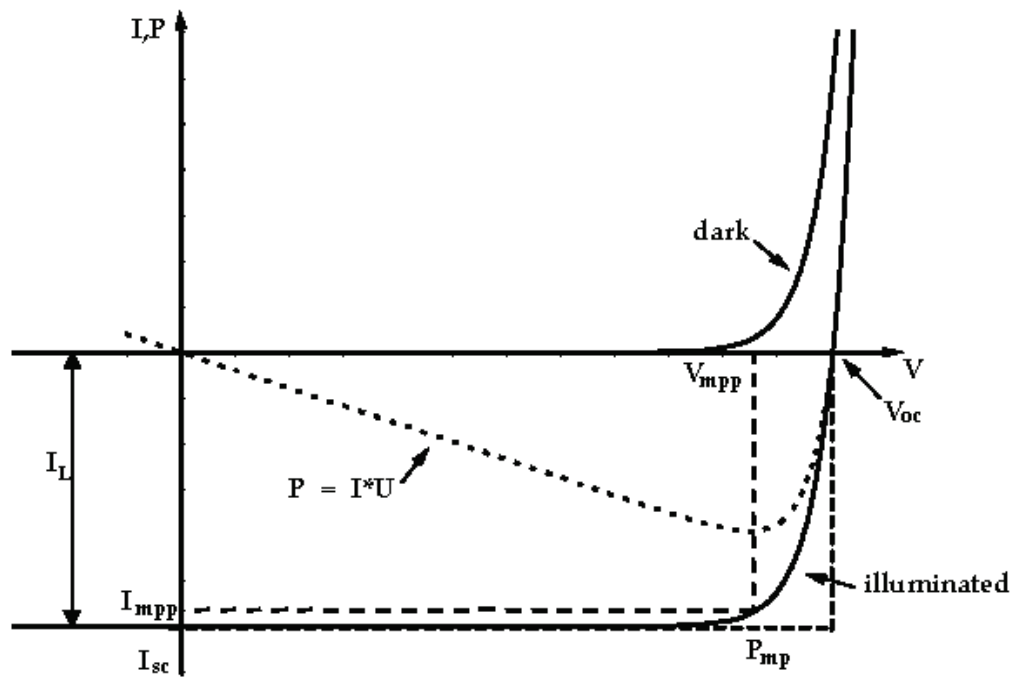

Fig. 6. Dark and illuminated current-voltage I-V curves of silicon solar cell.

Solar cells can be also usually connected in series in modules, creating an additive voltage. Connecting cells in parallel will yield higher amperage. Modules are then interconnected, in series or parallel, or both, to create the desired peak DC voltage and current.

\section{Silicon solar cells electrical and recombination parameters}

The solar cells have two categories of parameters: electrical parameters and recombination parameters. 


\subsection{Electrical parameters}

\subsubsection{Photocurrent}

The photocurrent density $I$ at the junction of solar cell is obtained from the excess minority carriers density of each illumination mode as follows (S. Madougou et al. 2004 et 2007a):

$$
I=\left.q D \frac{\partial \delta n(x)}{\partial x}\right|_{x=0}
$$

Where $q$ and $D$ are constants defined above.

\subsubsection{Voltage}

By means of Boltzmann's relation, the voltage V can be expressed as (J.F. Phyllips 1997):

$$
V=V_{T} \log \left(N_{B} \frac{\delta n(0)}{n_{i}^{2}}+1\right)
$$

Where, $V_{T}=\frac{k T}{q}$ is the thermal voltage, $\mathrm{n}_{\mathrm{i}}$ the intrinsic carriers density and $\mathrm{N}_{\mathrm{B}}$ the base doping density.

\subsubsection{Power}

The Power generated for the cell is given by:

$$
P=V I
$$

Where, $I$ and $V$ are the photocurrent and the voltage defined above.

\subsubsection{Fill factor}

The fill factor is given by (W. Shockley 1949):

$$
F F=\frac{V_{\max } I_{\max }}{V_{c o} I_{s c}}
$$

Where, $V_{\max }$ and $I_{\max }$ are voltage and current at maximum power point respectively. $V_{C O}$ is the open-circuit voltage and $I_{S C}$ is the short-circuit current.

\subsubsection{Series and shunt resistances}

The series resistance is given by (M. Wolf et al. 1963):

$$
R_{S}=\frac{V_{c o-} V}{I}
$$

The shunt resistance is given by (M. Wolf et al. 1963):

$$
R_{S h}=\frac{V}{I_{S C}-I}
$$

$I, V, V_{C O}$ and $I_{S C}$ are defined in sections 4.1.3 and 4.1.4 above. 


\subsubsection{Capacitance}

The capacitance is given by (Edoardo Barbisio 2000; S. Madougou et al 2004):

$$
C=\frac{q n_{0}}{V_{T}} \exp \left(\frac{V}{V_{T}}\right)
$$

Where, $n_{0}=\frac{n_{i}^{2}}{N_{B}}, V$ and $V_{T}$ are the voltage and the thermal voltage defined above.

\subsubsection{Internal quantum efficiency}

The internal quantum efficiency $\eta_{I Q E}$ is expressed by (S. Madougou et al. 2007b):

$$
\left(\eta_{I Q E}\right)=\frac{I_{S C}}{q[1-R] \Phi_{0}}
$$

$I_{S C}, R$ and $\Phi_{0}$ are defined above.

\subsection{Recombination parameters}

The different recombination parameters include: the diffusion length $L$, the minority carriers lifetime $\tau$ and the recombination velocities (Sf, $\mathrm{Sb}$ ).

\subsubsection{Diffusion length}

The excess minority carriers diffusion length is given by:

$$
L=\sqrt{\tau D}
$$

\subsubsection{Lifetime}

The excess minority carriers lifetime is given by:

$$
\tau=\frac{L^{2}}{D}
$$

\subsubsection{Recombination velocities (Sf, Sb)}

When $\mathrm{Sb}$ is higher, the photocurrent tends towards the open-circuit current. Thus, we have the relationship:

$$
(S f)=\left[\frac{\partial J}{\partial S f}\right]_{S b \rightarrow+\infty}
$$

When, Sf is higher, the photocurrent density tends towards its maximum value (short-circuit current). Thus, we have the following relationship:

$$
(S b)=\left[\frac{\partial J}{\partial S f}\right]_{S f \rightarrow+\infty}
$$




\section{Methods for determining the solar cells parameters}

Research indicates many techniques for determining electrical and recombination parameters of solar cells (S. Madougou et al. 2007b, 2005a; G. Sissoko et al 1996; S. K. Sharma et al. 1985).

In this part, we will present some methods of electrical and recombination parameters determination.

\subsection{Methods of electrical parameters determination}

For determining solar cells electrical parameters, several methods exist.

\subsubsection{The method based on the current-voltage characteristics}

In these categories of methods, the authors use an algorithm for extracting solar cell parameters from I-V-curve using a single or double exponential model (S. Dib et al. 1999; C.L. Garrido Alzar 1997). They also use a non linear least squares optimization algorithm based on the Newton model using the measured current-voltage data and the subsequently calculated conductance of the device (M. Chegaar et al. 2001). To extract the solar cells parameters, the authors also utilize an analysing method of the current-voltage (I-V) characteristics of silicon solar cells under constant multispectral illumination and under magnetic field (S. Madougou et al 2007a).

\subsubsection{The analytical method}

In this method, researchers use the data of some solar cells parameters (measured data of current, short circuit current, current at maximum power point, voltage, open circuit voltage, voltage at maximum power point) to determine others parameters.

\subsubsection{Others methods}

In those methods, we have:

- Methods using numerical techniques approaches;

- The vertical optimisation method;

- Etc...

All of these techniques can be extended or modified adequately to cover many cases of solar cells.

\subsection{Methods of recombination parameters determination}

Here, we present two methods of recombination parameters determination. The first method is a linear fit of Internal Quantum efficiency (IQE) reverse curves versus light penetration depth. The second one is a programming method. For each method, after determining the minority carriers diffusion length, we calculate the excess minority carriers lifetime and recombination velocities.

In this approach, new analytical expressions of recombination parameters were established.

\subsubsection{Fitting method}

It is a linear fit of the IQE reverse curves versus light penetration depth. From this linear fit, we extract the minority carriers diffusion length (S. Madougou et al. 2007b). Figure 7 presents an example of a linear fit of measured IQE reverse curves versus light penetration depth. 


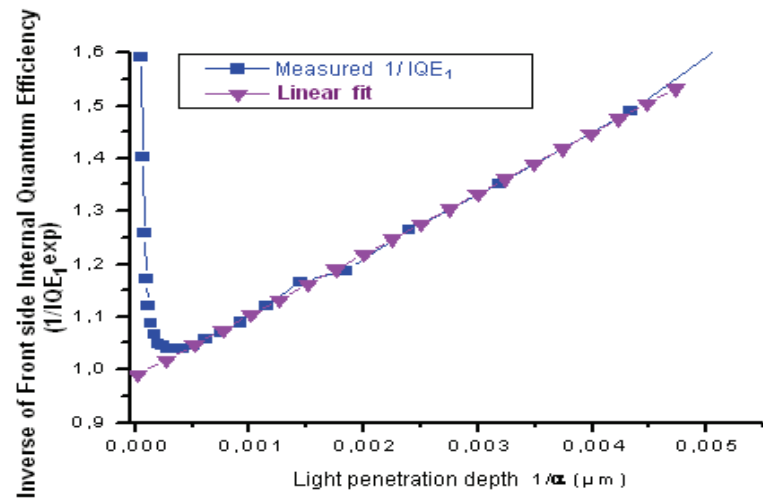

Fig. 7. Linear fit of the reverse of IQE with light penetration depth.

\subsubsection{Programming method}

Some researchers develop an algorithm to calculate the excess minority carriers diffusion length. This algorithm searches the weakness square type value between theoretical and measured internal quantum efficiency data. At this weakness square type value, we determine the corresponding diffusion length value of the solar cell (S. Madougou et al. 2007b).

\section{Conclusion}

This study shows that most of silicon solar cell is configured in N-P junctions. In these solar cells, recombination mechanisms occur in five regions and are mainly two types: recombination mechanisms in bulk and surface recombination. In practice, the solar cells can be illuminated using several illumination modes: under monochromatic light, under multispectral light, under intense light concentration or under other modes. Basic equations describe the behaviour of the excess minority carriers generated in the base of the solar cells. To understand the electronic behaviour in the study, the solar cell is modelled in an equivalent circuit containing a shunt resistance and a series resistance.

Silicon solar cells have two categories of parameters (electrical parameters and recombination parameters) which, the knowledge is very important to ameliorate the efficiency of the solar cells. Nowadays, many determination techniques of electrical and recombination parameters of solar cells exist. It is a great challenge for researchers to find a way to improve the solar cells efficiency. If this challenge is won, solar energy through photovoltaic energy can reveal itself to be a unique opportunity to solve energy and environmental problems simultaneously.

\section{References}

Alamo J. D., J. Eguren, and A. Luque (1981): "Operating limits of Al-alloyed high-low junctions for BSF solar cells". Solid-State Electronics. Vol. 24, pp. 415-420. ISSN: 0038-1101.

Chegaar M., Z. Ouennoughi, and A. Hoffmann (2001): A new method for evaluating illuminated solar cell parameters, Solid-state electronics, Vol. 45, pp. 293. ISSN: 0038-1101.

Dib S., M. de la Bardonne, A. Khoury (1999), "A new method for extraction of diode parameters using a single exponential model". Active and Passive Electronic Components. Vol. 22, PP. 157. ISSN 0882-7516. 
Edoardo Barbisio (2000): "Diffusion capacitance identification of PV cells". Proc. 16 European photovoltaic solar energy conference. ISBN 190291618 2. Date 1 - 5 May 2000, Glasgow, UK, pp 919 - 922.

Garrido-Alzar C. L. (1997): "Algorithm for extraction of solar cell parameters from I-V-curve using double exponential model". Renewable Energy. Vol. 10, pp. 125. ISSN: 0960-1481.

Glunz S. W., S. Janz, M. Hofmann, T. Roth, and G. Willeke (2006): "Surface passivation of silicon solar cells using amorphous silicon carbide layers". Proc. $4^{\text {th }}$ WCPEC, pp. 1016-1019. ISBN: 1-424-40017-1.

Madougou S., Nzonzolo, S. Mbodji, I. F. Barro, G. Sissoko (2004): Bifacial silicon solar cell space charge region width determination by a study in modelling: Effect of the magnetic field. Journal des Sciences. Vol.4, N³, pp. 116-123. ISSN 0851 - 4631.

Madougou S., B. Dieng, A. Diao, I. F. Barro, G. Sissoko (2005a): Electrical parameters for bifacial silicon solar cell studied in modelling: space charge region width determination. Journal des Sciences pour l'Ingénieur. Volume 5, pp. 34 - 39. (Senegal). ISSN 08514453.

Madougou S., I.F. Barro, G. Sissoko (2005b): Effect of magnetic field on bifacial silicon solar cell studied in modeling: space charge region width determination. Proc. 2005 Solar World Congress. PaperN¹979. ISBN 089553 1771. Date 6-12 August 2005, Orlando (Florida, USA).

Madougou S. F. Made, M. S. Boukary, G. Sissoko (2007a): I -V characteristics for bifacial silicon solar cell studied under a magnetic field. Advanced Materials Research: Trans Tech Publications Inc. Volume 18 until 19 pp. 303 - 312; (Zurich - Switzerland). ISSN 10226680.

Madougou S., F. Made, M. S. Boukary, G. Sissoko (2007b): Recombination Parameters Determination by Using Internal Quantum Efficiency (IQE) Data Of Bifacial Silicon Solar Cells. Advanced Materials Research. Trans Tech Publications Inc. Volume 18 until 19 pp. 313 - 324; (Zurich - Switzerland). ISSN 10226680.

Phyllips J.E., T. Titus and D. Hofmann (1997): Determining the voltage dependence of the light generated current in CuInSe2-Based solar cells using I-V measurements made at different light intensities. Proc 26th IEEE PVSC conference. isbn 0080438652. Sept. 30 - Oct. 3, Anaheim, CA, USA.

Sharma S. K., S.N. Singh, B.C. Chakravarty, and B.K. Das (1986): “Determination of minority carrier diffusion length in a p-silicon wafer by photocurrent generation method" Journal of Appl. Phys. Vol 60, N¹0. pp 3550 - 3552. ISSN: 0021-8979.

Shockley W., J. Bardeen and W. Brattain, "The Theory of P-N Junctions in Semiconductors and P-N Junction Transistors," Bell System Technical Journal, Vol 28: 1949, pp. 435 Semiconductive Materials Transistor. ISSN : 0005-8580.

Shockley W. and W. T. Read (1952): "Statistics of the recombination of holes and electrons," Physical Review. Vol. 87, pp. 835-842. ISSN: 0031-9007.

Sissoko G., C. Museruka, A. Correa, I. Gaye, A. L. Ndiaye (1996): “Light spectral effect on recombination parameters of silicon solar cell". Proc. World Renewable Energy Congress. Part III, pp 1487-1490. ISBN 0-7918-3763-7. Date 15 - 21 June. Denver - USA (1996).

Sze S.M. (1981): "Physics of semiconductors devices"; 2nd Edition, Wiley Interscience, Editor: John Wiley and Sons (WIE). ISBN-10 04710566 18. New York 11 p. 802.

Wang A., J. Zhao, and M. A. Green (1990): "24\% efficient silicon solar cells," Applied Physics Letters, vol. 57, pp. 602-604. ISSN 0003-6951.

WOLF M. and Hans RAUSCHENBACH (1963): Series resistances effects on solar cell measurement. Advanced energy conversion. ISSN 0196-8904. Volume 3, pp 445 - 479. Pergamon Press 1963. ISSN: 0196-8904. 


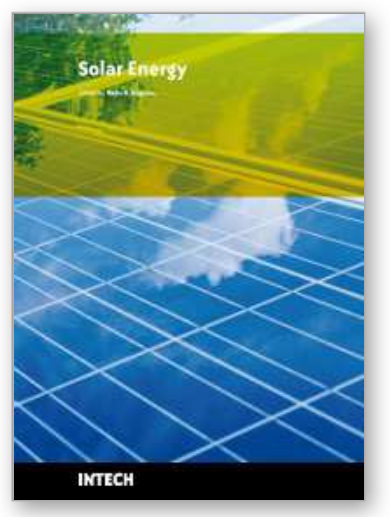

\author{
Solar Energy \\ Edited by Radu D Rugescu
}

ISBN 978-953-307-052-0

Hard cover, 432 pages

Publisher InTech

Published online 01, February, 2010

Published in print edition February, 2010

The present "Solar Energy" science book hopefully opens a series of other first-hand texts in new technologies with practical impact and subsequent interest. They might include the ecological combustion of fossil fuels, space technology in the benefit of local and remote communities, new trends in the development of secure Internet Communications on an interplanetary scale, new breakthroughs in the propulsion technology and others. The editors will be pleased to see that the present book is open to debate and they will wait for the readers' reaction with great interest. Critics and proposals will be equally welcomed.

\title{
How to reference
}

In order to correctly reference this scholarly work, feel free to copy and paste the following:

Saïdou, Madougou, Mohamadou Kaka and Gregoire Sissoko (2010). Silicon Solar Cells: Recombination and Electrical Parameters, Solar Energy, Radu D Rugescu (Ed.), ISBN: 978-953-307-052-0, InTech, Available from: http://www.intechopen.com/books/solar-energy/silicon-solar-cells-recombination-and-electricalparameters

\section{INTECH}

open science | open minds

\section{InTech Europe}

University Campus STeP Ri

Slavka Krautzeka 83/A

51000 Rijeka, Croatia

Phone: +385 (51) 770447

Fax: +385 (51) 686166

www.intechopen.com

\section{InTech China}

Unit 405, Office Block, Hotel Equatorial Shanghai

No.65, Yan An Road (West), Shanghai, 200040, China

中国上海市延安西路65号上海国际贵都大饭店办公楼405单元

Phone: +86-21-62489820

Fax: +86-21-62489821 
(C) 2010 The Author(s). Licensee IntechOpen. This chapter is distributed under the terms of the Creative Commons Attribution-NonCommercialShareAlike-3.0 License, which permits use, distribution and reproduction for non-commercial purposes, provided the original is properly cited and derivative works building on this content are distributed under the same license. 